\title{
КОМБІНОВАНА ОБРОБКА ДАНИХ САМОСТІЙНОГО МОНІТОРИНГУ РІВНЯ ГЛЮКОЗИ В КРОВІ
}

\author{
Г. П. Чуйко, О. В. Дворнік, Є. С. Дарнапук \\ Чорноморський національний університет імені Петра Могили
}

\begin{abstract}
Самостійний моніторинг рівня глюкози в крові протягом довгого періоду є одним із засобів моніторингу стану здоров'я. Дані представленого дослідження дозволяють корегувати лікування та спосіб життя людей, хворих на діабет. Тренди, мінливість та сезонність серій є базовими для запровадження таких рішень, для чого пропонується використовувати комбіновану обробку даних. Така обробка включає в себе сингулярно-спектральний аналіз (ССА) з використанням графріків Пуанкаре та дослідження статистичної автокореляційної фрункції (АКФ).

Об'єкт дослідження - 67-річний чоловік з довгою історією хвороби на діабет другого типу (T2D). Тести проводились три рази на тиждень за схемою «Понеділок-Середа-П'ятниця». Загальний час виміру складає 176 тижнів, тому часова серія має довжину в $\mathrm{N}=528$ семплів.

У результаті автокореляційна функція спрогнозувала сезонність серії. Сума плавного тренду, найменші коливання та залишки (шуми) і є моделлю серії. Такий підхід є стандартним для ССА. Знайдено плавний тренд із зміною. Найменший період (плюс сезонність) близький до шести місяців. Аналіз грасріку Пуанкаре показує випадкову природу короткострокової варіабельності серій, тоді як довгострокова має сезонність як основне джерело.

Тренд має випуклу фрорму. Виявлено затримку між початком лікування інсуліном та точкою зміни. Ця затримка близька до періоду найменших коливань (близько шести місяців). Результати сингулярно-спектрального аналізу, графріків Пуанкаре та досліджень автокореляційної функції узгоджуються між собою.
\end{abstract}

Ключові слова: рівень глюкози в крові, самостійний моніторинг, тренд, варіабельність, сезонність.

\section{COMBINED PROCESSING OF BLOOD GLUCOSE SELF-MONITORING}

\author{
G. P. Chuiko, O. V. Dvornik, Ye. S. Darnapuk \\ Petro Mohyla Black Sea National University
}

Background. The self-monitoring of Blood Glucose for a long time is a healthcare tool. The records study allows a correcting of a lifestyle and a cure for people with diabetes. The trend, seasonality, and variability of series are basic for such decisions. A combined processing is offered. It uses the Singular Spectrum Analysis (SSA), using Poincaré Plot (PP) as well as the statistical autocorrelation function (ACF) studies.

Materials and methods. The patient $(n=1)$ is a 67 -year-old male with the long history of type 2 diabetes (T2D). Tests were carried out three times a week. The scheme: "Monday-Wednesday-Friday" was in use. The total time was 176 weeks, so the time series has the length of $\mathrm{N}=528$ samples.

Results. The ACF has forecasted the series seasonality at first. A sum of the smooth trend, the slowest oscillations and the residuals (noises) was a model of the series. Such an approach is a standard of SSA. We found the smooth trend with a change-point. Slowest period, alias the seasonality, was close to six months. PP analysis shows the random nature of the short-term variability of series while the long-term one has the seasonality as the main source.

Conclusions. The trend has had a convex shape. We found a delay between the starting point for the insulin cure and the change-point. This delay was close to the period of slowest oscillations (about six months). The results of the SSA, PP analysis, and the ACF forecasts were consistent.

Key words: Blood Glucose, self-monitoring, trend, variability, seasonality. 


\title{
КОМБИНИРОВАННАЯ ОБРАБОТКА ДАННЫХ САМОСТОЯТЕЛЬНОГО МОНИТОРИНГА УРОВНЯ ГЛЮКОЗЫ В КРОВИ
}

\author{
Г. П. Чуйко, А. В. Дворник, Е. С. Дарнапук \\ Черноморский национальный университет имени Петра Могилы
}

\begin{abstract}
Самостоятельный мониторинг уровня глюкозы в крови в течение долгого периода является одним из средств мониторинга состояния здоровья. Данные представленного исследования позволяют корректировать лечение и образ жизни людей, больных диабетом. Тренды, изменчивость и сезонность серий являются базовыми для внедрения таких решений, для чего предложено использовать комбинированную обработку данных. Такая обработка включает в себя сингулярно-спектральный анализ (ССА) с использованием графриков Пуанкаре и исследования статистической автокорреляционной функции (АКФ).

Объект исследования - 67-летний мужчина с длинной историей болезни диабетом второго типа (T2D). Тесты проводились три раза в неделю по схеме «понедельник-среда-пятница». Общее время измерения составляет 176 недель, поэтому временная серия имеет длину в $\mathrm{N}=528$ сэмплов.

В результате автокорреляционная функция спрогнозировала сезонность серии. Сумма плавного тренда, малейшие колебания и остатки (шумы) и является моделью серии. Такой подход является стандартным для ССА. Найдено плавный тренд с изменением. Наименьший период (плюс сезонность) близок к шести месяцам. Анализ графрика Пуанкаре показывает случайную природу краткосрочной вариабельности серий, тогда как долгосрочная имеет сезонность как основной источник.

Тренд имеет выпуклую фрорму. Обнаружено задержку между началом лечения инсулином и точкой изменения. Эта задержка близка к периоду малейших колебаний (около шести месяцев). Результаты сингулярно-спектрального анализа, грасриков Пуанкаре и исследований автокорреляционной фрунцци согласуются между собой.
\end{abstract}

Ключевые слова: уровень глюкозы в крови, самостоятельный мониторинг, тренд, вариабельность, сезонность. 
Introduction. Self-monitoring of blood glucose (SMBG) is a healthcare tool in the last few decades [1]. Still, the benefits of SMBG for people with type 2 diabetes (T2D) are under doubts up to now [2-4]. There is a real conflict of views. They are the opposite: from "a waste of money" [2] up to "the opportunity to get a high investment-outcome ratio in the diabetes treatment" [3]. Besides, the gainful industry of devices and strips for SMBG has an own point of view in this struggle [1].

The systematic and full review [4] asserts that SMBG may improve the glycaemic control. Still, this is possible only within proper learning. The tuition must touch both the patients and healthcare experts. They should know which changes in the lifestyle and the cure are matched to the SMBG results. Trends and seasonality of the glycaemic level look as the key to such decisions. Hence, any SMBG needs the proper processing.

Each SMBG is a time series in fact. There does not matter the diversity of the glucose meters [5] or the varying in the frequencies of measuring [6]. Singular Spectrum Analysis (SSA) is a new method of the time series processing. It is needless to make any statistical assumptions about either signal or noise using SSA [7].

SSA has proved fruitful. It has become a standard tool in the processing of climatic, geophysical, genetic series etc. $[7,8,9]$. These signals have the large variability like medical series. The plus of SSA is a more exact forecast $[8,9]$. SSA is specially fit for the solving of below-listed problems [8]:

1) finding of trends;

2) smoothing and denoising;

3) extraction of seasonality components;
4) simultaneous extraction of cycles with small and large periods;

5) extraction of periodicities with varying amplitudes;

6) simultaneous extraction of complex trends and periodicities;

7) finding structure in a short time series;

8) change-point detection.

This list contains points, on which we will shed light using the SMBG processing. The effective algorithms for the SSA method had described in [10]. The new proper software was stated in [11] recently (via R-package).

Aims. The first aim of this paper is to show the power of SSA as for as an SMBG case study. It would be one of the first attempts to apply SSA for SMBG. The second aim is the offer of a combined processing with SSA, Poincaré Plots (PP) analysis and autocorrelation function (ACF). Such the set of tools allows crosschecking of the results reliability. The calculations and coding were made with Maple tools [12].

Materials and methods. The patient is a 67 year old male with the long history of T2D. Medications were per oral up to the $111^{\text {th }}$ week of observations. The multi-dose insulin (MDI) was involved from the $112^{\text {th }}$ week twice daily. It was the clinical decision of the responsible endocrinologist.

The regular tests were performed three times per week. The stable scheme: "Monday-WednesdayFriday" was in use. The total duration was 176 weeks, so the time series has the length $\mathrm{N}=528$ samples. All trials were before a morning meal with the glucose meter "SensoLite Nova".

Table 1

The measurement device properties

\begin{tabular}{|c|c|c|c|c|}
\hline Range & $\begin{array}{c}\text { Standard deviation within } \\
\text { range }\end{array}$ & $\begin{array}{c}\text { Relative accuracy } \\
\text { of strips }\end{array}$ & Total error of device & Memory capacity \\
\hline $20-600 \mathrm{mg} / \mathrm{dl}$ & $4.0-6.5 \mathrm{mg} / \mathrm{dl}$ & $3.0-4.5 \%$ & $8-16 \mathrm{mg} / \mathrm{dl}$ & 500 samples \\
\hline
\end{tabular}

Table 1 shows some technical options for the device. A reader can easily convert the used units (mg/dl) to another kind of them (mmol/l) by the dividing on factor 18 .

The mean value of lengthy SMBG series was about $151 \mathrm{mg} / \mathrm{dl}$. The standard deviation was equal to
$24.3 \mathrm{mg} / \mathrm{dl}$. Note the standard deviation of series is out of the range of the fourth column of Table 1. Hence, the accuracy of SMBG is never limited by device error [13]. 


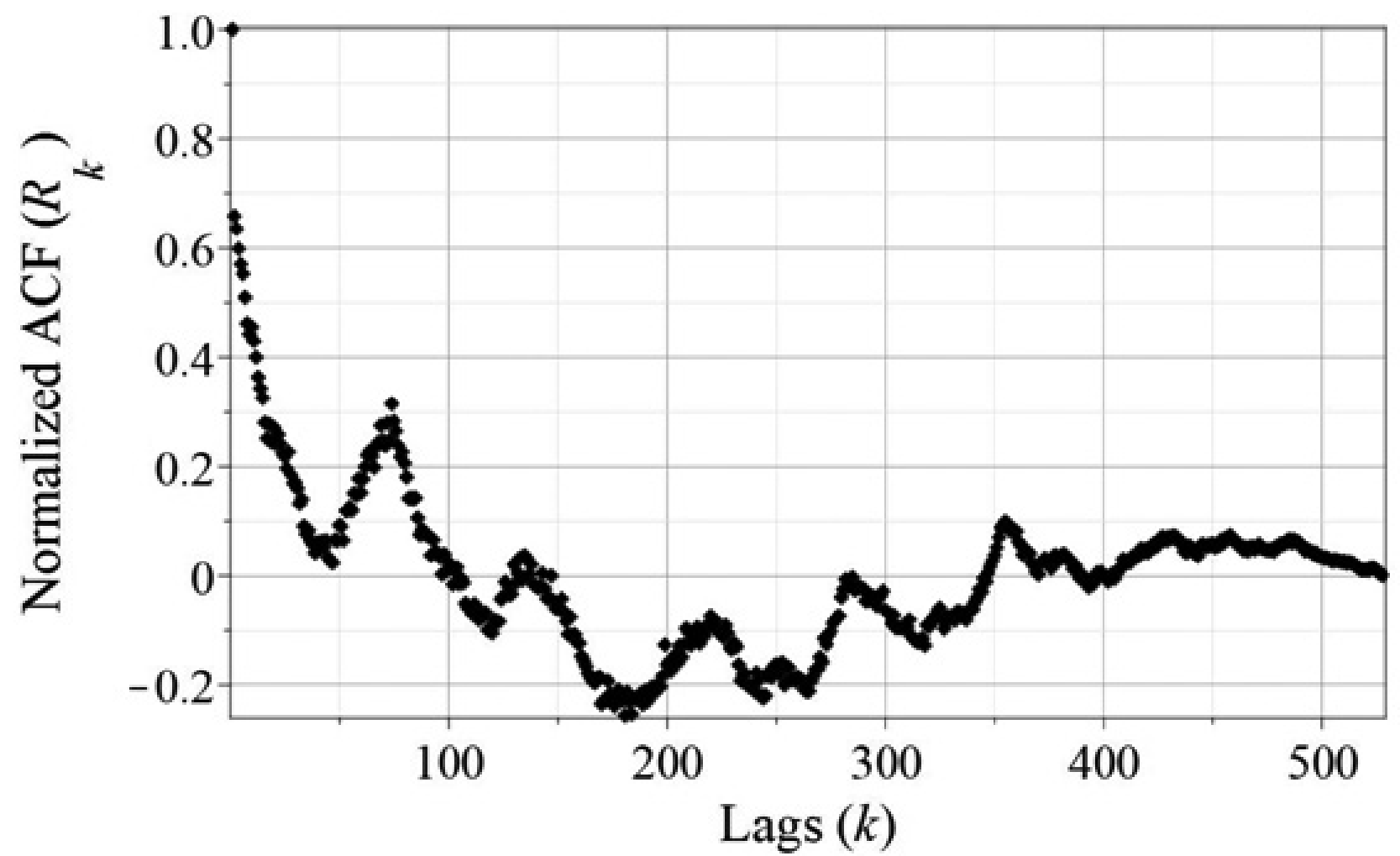

Fig. 1. The normalized statistical autocorrelation function of the SMBG series. A few slow oscillations are evident

Fig. 1 presents the normalized statistical autocorrelation function (ACF) for our series. The autocorrelation coefficients for a time series were defined by the formula:

$$
R_{k}=\frac{C_{k}}{C_{0}}
$$

There is:

$$
\left.\begin{array}{l}
C_{k}=\sum_{j=1}^{N-k}\left(x_{j}-\mu\right)\left(x_{j+k}-\mu\right) \\
0 \leq k \leq N-1
\end{array}\right\}
$$

and $\mu$ is the mean of the series $(x)_{1}^{N}=\left(x_{1}, x_{2}, \ldots, x_{N}\right)$.

Fig. 1 shows the weighty contribution of a slow oscillation into the signal. The longest period is roughly in the range (70-78) samples. It is close to six months (or 23-26 weeks). This result looks like the seasonality of "winter-summer" type [7, 8].

However, the said result requires the confirmation and refine. We recall the SSA is the suitable method for trends and seasonality extraction [8]. Thus, the preresult showed by Fig. 1 is expedient to confirm and clarify within this method. It will be performed in the next section.
General statistical metrics usually do not include glucose variability. That is right also for ACF and SSA. However, the variability is an important measuring of glycaemic control [13]. So, appropriate processing must include such study. We suggested Poincare Plots joined with ACF and SSA. This minimal set ensures the key indicators for the clinic decision-making: the trend, the seasonality and the variability for the glycaemic level.

Results and discussions. Grouping of singular triples. The papers [7-11] describe the basic of SSA in detail. The basic algorithm comprises four stages. They are embedding, singular value decomposition (SVD), grouping, and reconstruction.

Let divide the initial series into a set of $\mathrm{K}=\mathrm{N}-\mathrm{L}+1$ one-lagged vectors with the same length $\mathrm{L}$. Each of these vectors is a column in the trajectory matrix with the dimensions $\mathrm{L}^{\times} \mathrm{K}$ [7-11]. This matrix is the main result of the embedding.

Thus, it predicts a choice of the length of the window $2 \leq \mathrm{L} \leq \mathrm{N}$. Theoretic idea tells us that $\mathrm{L}$ should be large enough but not greater than N/2. If so, we have taken $\mathrm{L}=264=\mathrm{N} / 2$. Thus, our trajectory matrix has had almost the quadrate shape (264 x 265). 


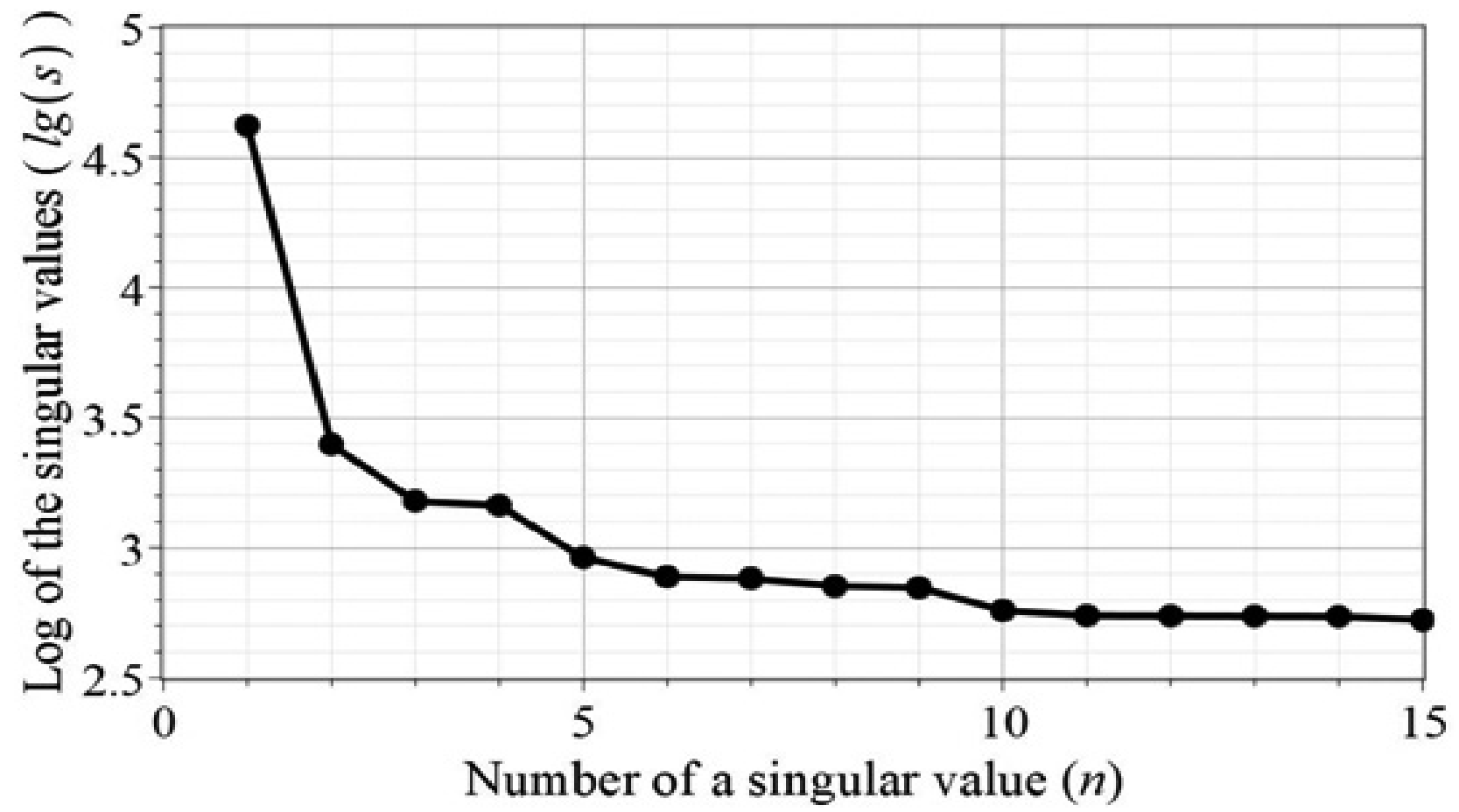

Fig. 2. First dozen of singular values in the semi-log scale Singular values are arranged in a descending order, forming characteristic «elbows»

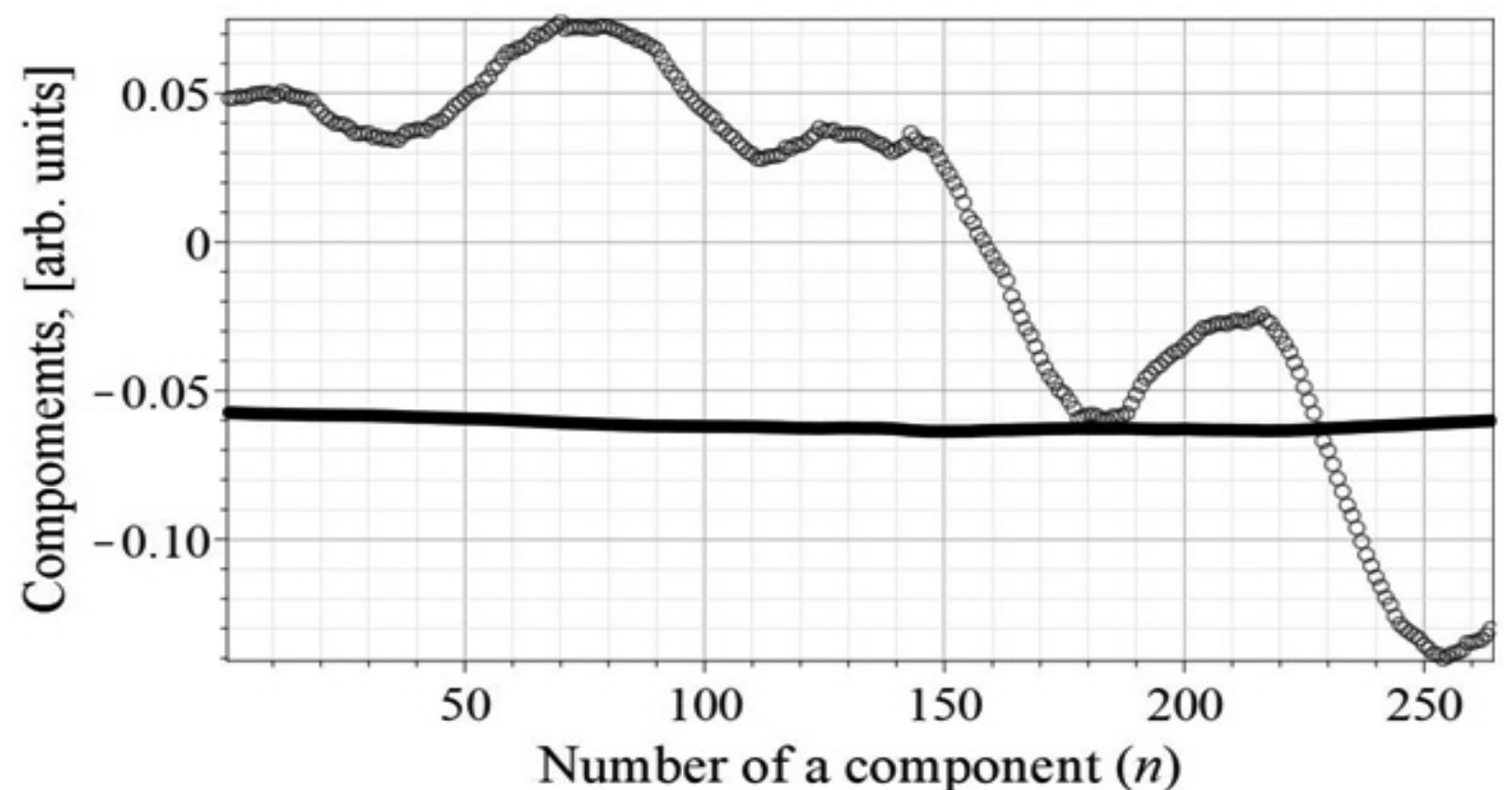

Fig. 3. 1D-diagrams for the components of right singular vectors. The solid circles show the first vector; open circles - the second one

Fig. 2 shows the first dozen of singular values (the complete set is ) in the semi-log scale. Such a graph is often termed as Cattell's scree-test [14]. Deflections, or so-called elbows, are the key feature of the test understanding. Three first elbows are connected with third, fifth and tenth points. Further elbows are much less evident.

Hence, we can consider the first pair; first four or first nine so-called singular triples. These singular triples are the results of SVD. Each triple contains one of the singular values as well as two singular vectors: the left and the right. The listed above sets are enough for the less or more exact approximation of the experimental series. A way of the singular triples selection and their interpretation is termed as the grouping [7-11].

The grouping is the sole creative process demanding some experience and intuition. The authors of [7] 
advised pay attention to the singular vectors of triples. The 1D-charts for singular vectors are similar to the single components of the series. Smooth, slightly changing charts of a permanent sign most often correspond to the trends of series. Such 1D-chart for first two singular vectors is shown on Fig. 3.

The first singular vector (solid circles) is a quite smooth and slow changing sequence without a change of sign.

The second one (open circles) is beyond the above conditions. This vector is a family member of long-period oscillations. Note that its period on the Fig. 3 is close to one detected on Fig. 1. Afterward, we must consider the second triple together with the third and the fourth as the next group. This group describes the slow oscillations probably with the varying amplitudes.

The rest of the triples, beginning from the fifths, we will recognize as "a noise". Thus, we will ignore and classify as a noise all oscillations with shorter periods. Yet, we could consider them if it would necessary. To do it we can to take the next group of triples: from the fifth to the ninths.

Here, however, is the question "when should be the stopping of this process?" If the standard deviation of the "noise" were of the same kind as the total error of the measuring then the stopping would seem as sensible.

Trend, slowest oscillations and "noise". We have decided above to use only two or three group of singular triples:

1. The first triple corresponds to first and greatest singular value. This triple defines the trend of series.

2. The second group consists of three next triples. This group describes the slowest oscillations of series, which have detected by the Fig. 1 and the Fig. 3 .

3. The third group contains the next five triples. This group can either be taken into account, or not, depending on the conditions. It determines the oscillations with shorter periods, the relevance of which is still under question.

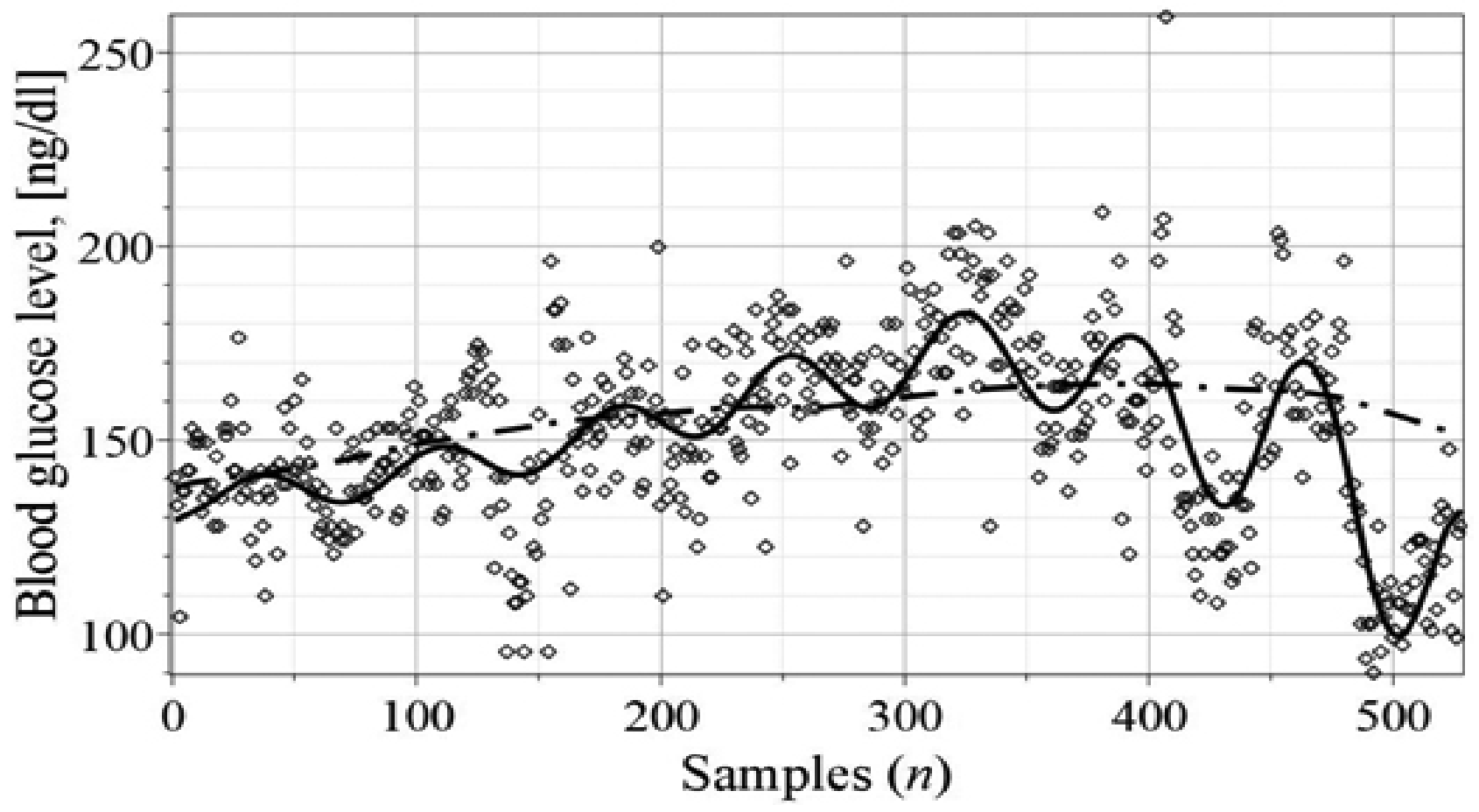

Fig. 4. Trends as dashed lines and slow oscillations as solid lines showed on the background of initial SMBG series (points). The graph displays the approximation with two groups of singular triples

Fig. 4, 5 presents the trend of SMBG series by dashed lines. Solid lines show the two different approximations on the background of measured series (points). Fig. 4 presents the approximation with two groups of triples.

The trend line is a bit, but obvious convex. It allows the detecting of the change-point [8]. This point is at $401^{\text {th }}$ sample that is on the $134^{\text {th }}$ week of observation.
Thus, the trend was negative, i.e. the glycaemic level was increasing, up to the change-point. The trend was changed to stable positive afterward the point. Note that the trend range is close to the standard deviation of the initial data. Hence, without the trend extracting the change-point would be never noticeable. 
The unexpected large delay between this changepoint and the above-mentioned $112^{\text {th }}$ week was found. The matter is that after the $111^{\text {th }}$ week the MDItreatment has been started. This delay is virtually equal to the period of slowest oscillations that is close to six months (24 weeks more exactly).

We cannot take a liberty for discussions about of a meaning of this delay for endocrinologists. Yet, we invite to pay attention to the remarkable fact despite that was found in the case study. Medics prefer to deal with the groups of homogeneous patients and often consider a case study as the waste of time. However, the situation is changing gradually. Here we take in mind the novel concept of the person-centered medicine [15]. The case studies are in focus of this concept.
The period of slowest oscillations has turned out about 72 samples what is equal to 24 weeks. It good matches the periods from Figs. 1 and 3. Hence, the slow oscillations with the period close to six months are inherent on series. The amplitude of them increases since the change-point area.

Slow oscillations have an effect on ACF (Fig. 1) detected on the charts of singular vectors (Fig. 3 ) and appear in approximate series (Fig. 4 and 5). They have all signs of the seasonality [7-9]. The seasonality period (about six months, or the winter-summer interval) indicates the effect of the seasonal diet and physical activity on blood glucose level.

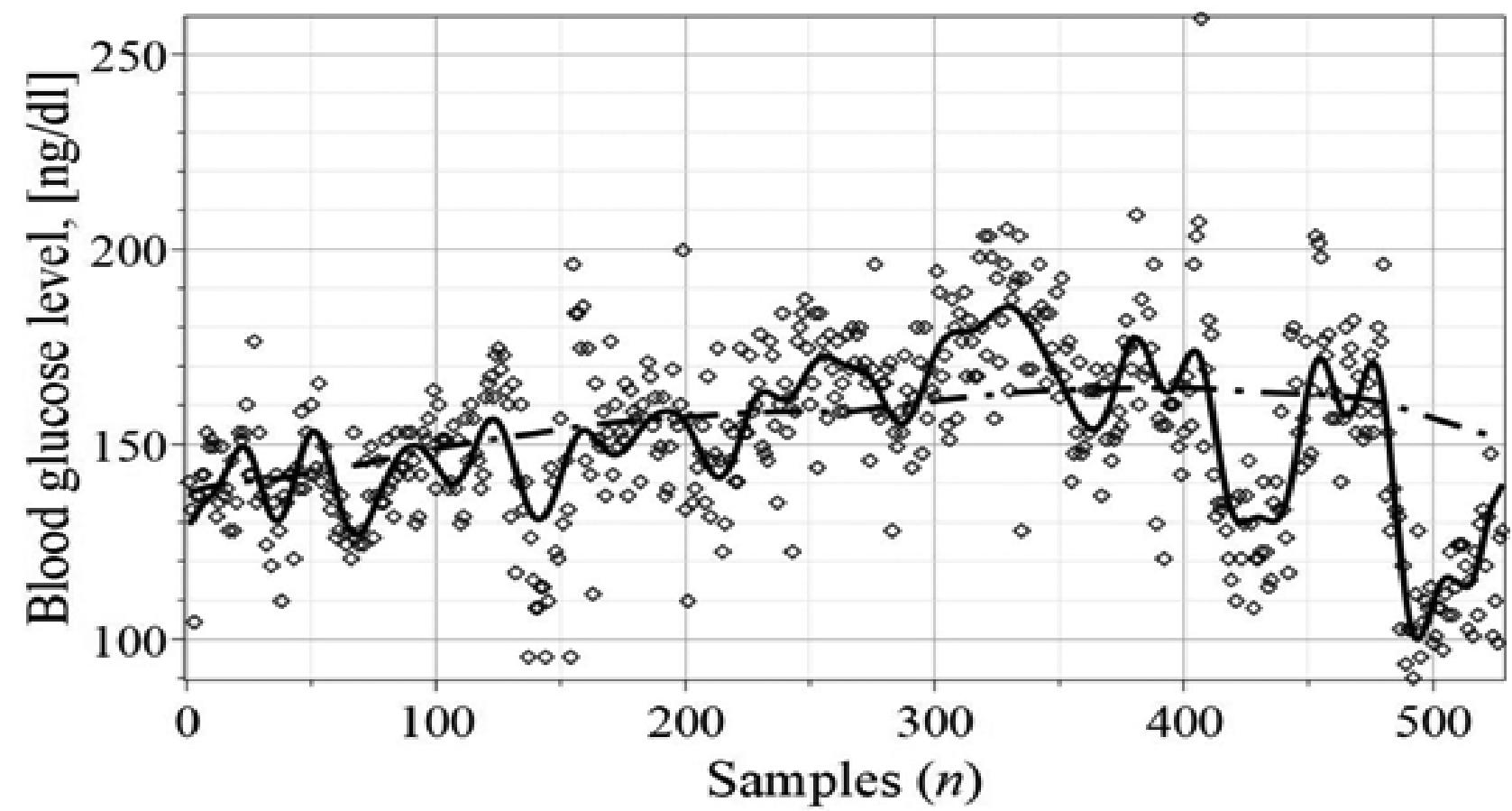

Fig. 5. Trends as dashed lines and slow oscillations as solid lines showed on the background of initial SMBG series (points). The graph shows the approximation with three groups of singular triples

Fig. 5 demonstrates only the minor effects caused by faster oscillations. They have the roughly twiceshorter periods and probably the same seasonal origin. Their amplitudes are much lower than for the abovementioned slowest oscillations. Thus, we can see only subtle hints of their being in Fig. 1.

Examine the standard deviations for the "noise". Consider three consequent approximations: with one, two or three groups. We got the row of estimates in the descending order: $s d_{1} \approx 22 ; s d_{2} \approx 17 ; s d_{3} \approx 15$ (in $\mathrm{mg} / \mathrm{dl}$ ).

The comparing of these estimates with the total error of the device ( $\mathrm{mg} / \mathrm{dl}$, see Table 1) confirms that the approximation with two groups is quite enough in the sense of accuracy. The next step (Fig. 5) looks already a few "over and above" that.

Long-term and short-term variability of SMBG (Poincarè Plot). Poincare plots were first applied for the variability analysis of the heart rate $[16,17]$. Yet, the variability is inherent not only in the heart rate but in the wider spectrum of medical signals [18]. The author [19] has suggested Poincaré plots as an "elegant way to visually display the glucose variability".

A Poincaré Plot is a way of the picturing of a time series $(x)_{1}^{N}=\left(x_{1}, \ldots, x_{n}, \ldots, x_{N}\right)$. Two one-lagged vectors $(x)_{2}^{N},(x)_{1}^{N-1}$ form a 2D-array. The scatter plot $x_{n+1}$ 
against $x_{n}$ for all $n=1, \ldots, N-1$ is termed as Poincaré Plot (PP). We can consider it as an embedding of two above vectors into $2 \mathrm{D}$-space (a plane). The one-delay map of the series on the plane is another interpretation of PP.

Authors [17] have suggested two descriptors for PPs. We would like to write down these here in the form that has been offered by the paper [16]:

$$
\left.\begin{array}{l}
S D 1=S D\left(\frac{(x)_{2}^{N}-(x)_{1}^{N-1}}{\sqrt{2}}\right) \\
S D 2=S D\left(\frac{(x)_{2}^{N}+(x)_{1}^{N-1}}{\sqrt{2}}\right)
\end{array}\right\}
$$

Here $S D\left((x)_{1}^{N}\right)$ is the operator of the standard deviation for the time series. The descriptors (1) are the standard deviations of two different parts of the signal. The first of then (SD1) characterize the shortterm variability of a signal. The second one (SD2) describes the long-term variability.

Its ratio $R=\frac{S D 1}{S D 2}$ presents the randomness of the signal [16-19]. One can see that our PP has a shape as if an ellipsoid (see Fig. 6). The longer axis coincides with the direction of the so-called identity line that is the bisectrix. The shorter axis is normal to this direction. We got the following results: $S D 1 \approx 14 \mathrm{mg} / \mathrm{dl}, S D 2 \approx 31 \mathrm{mg} / \mathrm{dl}$ and $R \approx 0.45$.

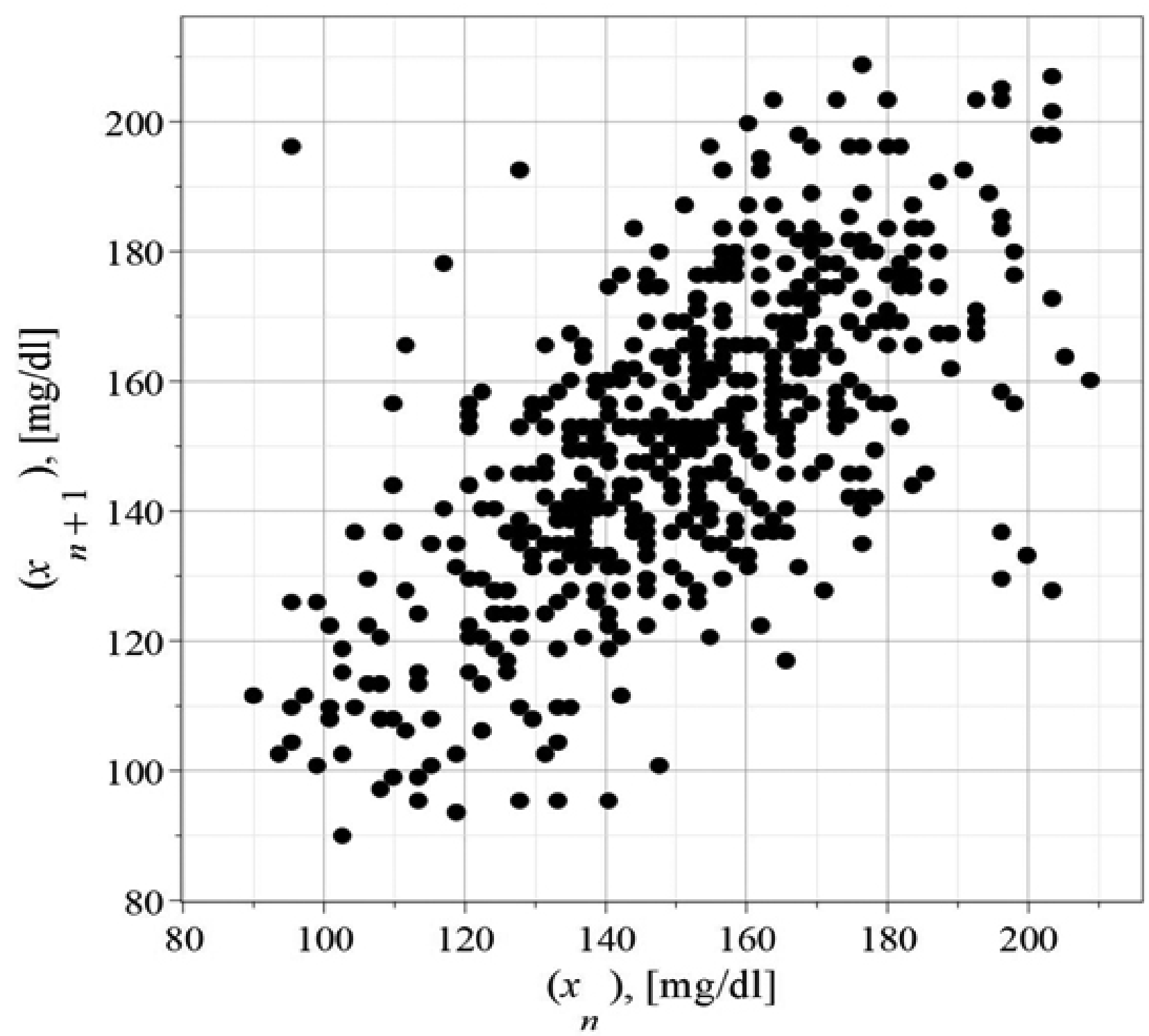

Fig. 6. The Poincaré Plot of the SMBG series 
The first of them (SD1) turned out to be close to the error of the device (see Table 1). Hence, the short-term variability probably has the noise as its main basis. As well, one can see that up to 45 percent of the signals have the random origin. The second one (SD2) surely exceeds the device error. Thus, we must consider the long-term variability of the signal as caused by slow oscillations (the seasonality). Therefore, the results of the Poincaré Plot analysis support the conclusions of the above sections.

Conclusions. The healthcare experts have pointed out two main skills (operational and interpreting), which are necessary at the SMBG [20]. Patient must be familiar not only with the glucose-measuring.

Appropriate interpretation and processing of the SMBG results is basis not only for the clinic decision-making but also for the adjustment of the patient lifestyle taking in the mind current results. Both purposes require the simple

\section{Bibliography.}

1. Point: Self-monitoring of blood glucose in type 2 diabetic patients not receiving insulin: The sanguine approach / Ipp E., Aquino R. L., Christenson P. // Diabetes Care. 2005. - № 28. - P. 1528-1530.

2. Counterpoint: Self-monitoring of blood glucose in type 2 diabetic patients not receiving insulin: a waste of money / Davidson M. B. // Diabetes Care. - 2005. № 28. - P. 1531-1533.

3. Self-measurement of blood glucose in patients with type 2 diabetes: a health economic assessment / Weber C., Neeser K., Schneider B., Lodwig V. // J. Diabetes Sci. Technol. - 2007. - № 1. - P. 676-684.

4. Self-monitoring of blood glucose in type 2 diabetes: systematic review / Clar C., Barnard K., Cummins E. et al. // Health Tecnol. Assess. - 2010. - № 12. - P. 1-140.

5. Glucose meters: a review of technical challenges to obtaining accurate results. / Tonyushkina K., Nichols J. H. // J. Diabetes Sci. Technol. - 2009. - № 3. P. 971-980.

6. Blood glucose meters. Performance of devices on the Dutch market / van Drongelen A. W., de Bruijn A. C. P., van Elk M. et al. // RIVM Letter report 20160087. - 2016. - Available from: https://www.rivm.nl/ bibliotheek/rapporten/2016-0087.pdf.

7. Analysis of Time Series Structure: SSA and Related Techniques / Golyandina N., Nekrutkin V., Zhigljavsky A. - CRC Press: Chappman \& Hall. - 2001. - 320 p.

8. Singular Spectrum Analysis: Methodology and Comparison / Hassani H. // J. Data Sci. - 2007. № 5. - P. 239-257.

9. A glance at the applications of Singular Spectrum Analysis in gene expression data / Hassani H., Ghodsi Z. // Biomol. Detect. Quantif. - 2015. - № 4. - P. 17-21. but informative procedure of the records processing. We have shown above some kind of such processing.

Resume all said above in a few points.

1. The Singular Spectrum Analysis proved to be a powerful method of processing for the selfmonitoring of blood glucose. The trend and slowest oscillation (the seasonality) are easily extractable from SMBG by SSA. Namely, the trend, the seasonality, and the variability are keys to the interpretation of SMBG.

2. The results of statistical autocorrelation analysis, Poincaré plot analysis, and SSA are in good agreement.

3. The short-term variability of the SMBG has mainly the random nature. The long-term variability caused mostly by slowest oscillation that is the seasonality.

4. A certain delay has existed between the start of the multi-dose insulin (MDI) cure and the change-point of the SMBG trend. This delay was close to the period of slowest oscillation (close to six months).

10. Computation- and space-efficient implementation of SSA / Korobeynikov A. // Stat. Interface. - 2010. № 3. - P. 357-368.

11. Multivariate and 2D Extensions of Singular Spectrum Analysis with the Rssa Package / Golyandina N., Korobeynikov A., Shlemov A., Usevich K. // J. Stat. Softw. - 2015. - № 67. - P. 1-78.

12. Index of New Commands and Packages in Maple 18. Online Help. -Maplesoft, a division of Waterloo Maple Inc. - 2018. - Available from: https://www.maplesoft. com/support/help/maple/view.aspx?path=updates\%2f Maple18\%2findex.

13. Towards Harmonized Data Processing in SMBG / Zulj S., Seketa G., Magjarevic R. // Precision Medicine Powered by pHealth and Connected Health. IFMBE Proceedings. - 2018. - № 66. - P. 65-68.

14. The scree test for the number of factors / Cattell R. B. // Multivariate Behavioral Research. - 1966. - № 1. P. 245-276.

15. Traditional, complementary and alternative medical systems and their contribution to personalisation, prediction and prevention in medicine - personcentred medicine / di Sarsina P. R., Alivia M., Guadagni P. // EPMA Journ. - 2012. - № 3. P. 1-10.

16. Filtering Poincaré plot / Piskorski J., Guzik P. // Comput. Methods Sci. Thechnology. - 2005. - № 11. - P. 39-48.

17. Quantitative beat-to-beat analysis of heart rate dynamics during exercise / Tulppo M. P., Makikallio T. H., Takala T., Seppanen T. V. H. H. // Am J Physiol. - 1996. № 271. - P. H244-H252.

18. Poincarè Plots in Analysis of Selected Biomedical Signals / Kitlas-Golińska A. // Stud. LOGIC, Gramm. Rhetor. - 2013. - № 35 (48). - P. 117-127. 
19. Poincaré Plot Quantification for Assessing Glucose Variability from Continuous Glucose Monitoring Systems and a New Risk Marker for Hypoglycemia: Application to Type 1 Diabetes Patients Switching to Continuous Subcutaneous Insulin Infusion / Crenier L. // Diabetes Technol. Ther. - 2014. - № 16. - P. 247-254.

20. The Two Skill Sets of Self-Monitoring of Blood Glucose Education: The Operational and the Interpretive / Austin M. M. // Diabetes Spectrum. - 2013. - № 26 (2). - P. 83-90.

\section{References.}

1. Ipp, E., Aquino, R. L., Christenson, P. (2005). Point: Selfmonitoring of blood glucose in type 2 diabetic patients not receiving insulin: The sanguine approach. Diabetes Care., 28, 1528-1530. doi:10.2337/diacare.28.6.1528.

2. Davidson, M. B. (2005). Counterpoint: Self-monitoring of blood glucose in type 2 diabetic patients not receiving insulin: a waste of money. Diabetes Care, 28, 15311533. doi: 10.2337/diacare.28.6.1531C.

3. Weber, C., Neeser, K., Schneider, B., Lodwig, V. (2007). Self-measurement of blood glucose in patients with type 2 diabetes: a health economic assessment. J. Diabetes Sci. Technol., 1, 676-84. doi: 10.1177/193229680700100511.

4. Clar, C., Barnard, K., Cummins, E., Royle, P., Waugh, N. (2010). Self-monitoring of blood glucose in type 2 diabetes: systematic review. Health Tecnol. Assess., 12, 1-140. doi: 10.3310/hta14120.

5. Tonyushkina, K., Nichols, J. H. (2009). Glucose meters: a review of technical challenges to obtaining accurate results. J. Diabetes Sci. Technol., 3, 971-980. doi:10.1177/193229680900300446.

6. van Drongelen, A. W, de Bruijn, A. C. P., van Elk, M., Lamme, E. K., van der Maaden, T., Rosze, B., Schooneveld, B. C., Jansseet, R. (2016). Blood glucose meters. Performance of devices on the Dutch market. RIVM Letter report 2016-0087 [cited 2018 May 5]. Available from: https://www.rivm.nl/bibliotheek/ rapporten/2016-0087.pdf.

7. Golyandina, N., Nekrutkin, V., Zhigljavsky, A. (2001). Analysis of Time Series Structure: SSA and Related Techniques. Chappman\&Hall, CRC Press. doi:10.1198/ jasa.2002.s239.

8. Hassani, H. (2007). Singular Spectrum Analysis: Methodology and Comparison. J. Data Sci., 5, 239-257. doi:10.3189/172756506781828863.

9. Hassani, H., Ghodsi, Z. (2015). A glance at the applications of Singular Spectrum Analysis in gene expression data. Biomol. Detect. Quantif., 4, 17-21. doi:10.1016/j.bdq.2015.04.001.
10. Korobeynikov, A. (2010). Computation- and spaceefficient implementation of SSA. Stat. Interface., 3, 357-368. doi:10.4310/SII.2010.v3.n3.a9.

11. Golyandina, N., Korobeynikov, A., Shlemov, A., Usevich, K. (2015). Multivariate and 2D Extensions of Singular Spectrum Analysis with the Rssa Package. J. Stat. Softw., 67, 1-78. doi:10.18637/ jss.v067.i02.

12. Index of New Commands and Packages in Maple 18. Online Help. Maplesoft, a division of Waterloo Maple Inc. 2018. [cited 2018 May 5] Available from: https:// www.maplesoft.com/support/help/maple/view.aspx?pa th=updates\%2fMaple18\%2findex.

13. Zulj, S., Seketa, G., Magjarevic, R. (2018). Towards Harmonized Data Processing in SMBG. In: Maglaveras N., Chouvarda I., de Carvalho P. (eds) Precision Medicine Powered by pHealth and Connected Health. Springer, Singapore. IFMBE Proceedings, 66, 65-68. doi:10.1007/978-981-10-7419-6_11.

14. Cattell, R. B. (1966). The scree test for the number of factors. Multivariate Behavioral Research. 1, 245-276.

15. di Sarsina, P. R., Alivia, M., Guadagni, P. (2012). Traditional, complementary and alternative medical systems and their contribution to personalisation, prediction and prevention in medicine - person-centred medicine. EPMA Journ., 3, 1-10. doi:10.1186/18785085-3-15.

16. Piskorski, J., Guzik, P. (2005). Filtering Poincaré plot. Comput. Methods Sci. Thechnology., 11, 39-48. doi:10.12921/cmst.2005.11.01.39-48M.P.

17. Tulppo, M. P., Makikallio, T. H., Takala, T. E. S., Seppanen, T. V. H. H. (1996). Quantitative beat-tobeat analysis of heart rate dynamics during exercise. Am J Physiol., 271, H244-H252. doi: 10.1152/ ajpheart.1996.271.1.H244.

18. Kitlas-Golińska, A., (2013). Poincarè Plots in Analysis of Selected Biomedical Signals, Stud. LOGIC. Gramm. Rhetor., 35 (48), 117-127. doi:10.2478/slgr-2013-0031.

19. Crenier, L., (2014). Poincaré Plot Quantification for Assessing Glucose Variability from Continuous Glucose Monitoring Systems and a New Risk Marker for Hypoglycemia: Application to Type 1 Diabetes Patients Switching to Continuous Subcutaneous Insulin Infusion. Diabetes Technol. Ther., 16, 247-254. doi:10.1089/ dia.2013.0241.

20. Austin, M. M. (2013). The Two Skill Sets of SelfMonitoring of Blood Glucose Education: The Operational and the Interpretive. Diabetes Spectrum., 26 (2), 83-90. doi:/10.2337/diaspect.26.2.83. 